\title{
Implementation Method of Party Construction Work among College Students Based on Information Technology under New Trend
}

\author{
Lin Kai \\ Wuhan University of Technology, Paty Committee Office Wuhan, 430070 \\ Email: 826754797@qq.com
}

Key Words: New Trend, Student Party Construction, Colleges and Universities, Information Technology

\begin{abstract}
Party members of college students are outstanding students as well as builders and successors of socialism. The main task of party construction among college students is to cultivate talents and cultivate high-quality talents with knowledge, ability and belief for the party and the country. Therefore, implementing party construction work among college students in a better way and ensuring the cultivation quality of party members of college students is in direct relationship with the development of future career of our country. Party construction work among college students is an effective way of improving ideological and political work of college students under the new trend. Standardize organization development program, form all kinds of statements, make auxiliary analysis and strengthen the active consciousness of party spirit exercise among students with adoption of student party construction management office automation system and then improve the scientific level of student party construction work in colleges and universities.
\end{abstract}

\section{Introduction}

With the deepening of digital information model in nowadays, the colleges and universities also need to move forward with times. Student party construction work in colleges and universities has been included in digital information management model, become part of digital information model and played an important role in colleges and universities with the deepening of digital information construction. In view of the management situation of student party construction in colleges and universities, it is easy to find out that many colleges and universities still adopt traditional manual management model, which has caused problems of low management efficiency, troublesome inquiry, complicated statistics, not standard material management etc inevitably, which will affect the teaching management, student management, logistics service and party construction etc in colleges and universities. Therefore, the adoption of digital information management model can avoid this kind of problem in a better way and then improve the effectiveness of management.

\section{New Situation Faced by Student Party Construction in Colleges and Universities}

Continuous deepening of higher education reform brings about attack and opportunity to student party construction work

With the continuous deepening of our higher education reform and coming of its popularization, the gradual implementation of credit system as well as deepening of logistics social reform has become an irreversible objective trend. The community activities and dormitories etc. have become the main methods and sites for study and life of students and the collective consciousness and class concept of students have been gradually weakened, which has brought about attack to traditional student party construction work. Under such situation, how to set up party organization reasonably and play the exemplary leading role of student party members in these sites fully is an important issue that needs to be solved urgently for student party construction work.

Popularization of network technology and development of informatization challenge the traditional working method

In the era of information network, internet as the "fourth media" is becoming a new way of 
acquiring knowledge and information for contemporary college students, which has extensive and profound influence on study, life and even ideas of college students. How to gain profit, avoid harm, play the important role of internet as new carrier and important method in cultivating people and shaping people and implement student party construction in a better way is a subject that needs to be solved urgently.

There are some new characteristics in the idea and behavior of college students under new trend

First is that value orientation is becoming increasingly pragmatic, stressing self-development and realization of self-value and presenting the tendency of utilitarianism and individualism. The reform of social selection and graduation employment system produces profound changes in the concept of contemporary college students, who pay more attention to the realization of self-value and benefits, improvement of self-quality and ability and presenting more pragmatic characteristics.

Second is strengthening of autonomous consciousness and change and innovation consciousness as well as relative weakening of collective consciousness, unity and cooperation and spirit of enterprising. The contemporary college students are no longer satisfied with passive acceptance for new things and not satisfied with preach and report either while they are stressing the development of personality. These changes have produced new challenges for student party construction work.

\section{Design of Party Construction Information System}

At present, the student party information management system of our school mainly adopts two modules of dynamic website and office automation system. Dynamic website is mainly used to present related material collected from party construction database as well as linking related information, notice, table and other content, such as list of party members, publicity of party activists, party contacting class, list of wards for loan as well as overview of helping poor students and tuition payment information and feedback etc; also include information input of related managers, inquiry, summary, statistics and statement etc. The related personnel include: school leaders, party branch secretary of second-level College, party branch secretary of student community, the Youth League Secretary, political instructor, monitor and league secretary etc. System module: set up core platform for digital party construction, mainly including party electronic information bank, management of party construction, interaction among party members, statistical analysis and palmtop party construction five modules. Set up standardized working process based on business order of student party development in higher vocational colleges and make stage treatment for related workers of each level.

Party construction (1) Organize construction management: implement information and organization for the whole process of organization construction through organization management module, including party committee transition, branch transition, new party, party revocation, party ordering, party inquiry and other full electronic office. (2) Organization awards management: after winning awards, member of branch committee and member of party committee organize the awards; publicize the organization awards after approved by branch secretary.

Party member management (1) Party member file management: new party member, party member change, party member development, full information filing, updating and deletion during party member transfer. (2) Party dues management: set up standard of party due, party members paying normal party dues, party members paying special party dues, party dues situation of branch party members, party dues expenditure, branch party dues statistics, party dues situation of party committee etc to make statement generation. (3) Party member awards management: confirm recognition scope, make selection criteria, recommend selection, confirm object, examine approval, make recognition decision and promote advanced deeds. After party members attained corresponding awards, organization committee and publicity committee file individual awards.

Organization development, accomplish whole process of party joining, fill in party joining application form, become activist, develop objects, probationary party member, electronic examination and approval of whole process of formal party member.

Democratic appraisal; notify meeting, electronic evaluation, publicize and file evaluation result of each meeting. 
Plan summary; branch committee, party committee and party organization make annual plan, annual working plan, revise and file respectively.

Party member construction; make party member plan (annual), party member commitment, file democratic appraisal of party member.

Party electronic information management; (1) Electronic file management; make classification and filing management for personnel files of party members of each level. (2) File data cabinet; provide file management service such as automatic inputting of paper file scanning for each management department and each record includes file number, file name, publisher and publishing time etc. (3) Date import; after filling in related party member information etc, import the information into the system and the system will generate main organization structure and personnel information automatically. (4) Annual report; export the party member information in system data in designated format and generate the basic report format of reported organization automatically. (5) Organization setting; set up basic party organization and administrative department information. (6) Personnel setting; provide two query staff methods based on party organization and department accordingly. It can check and revise personnel information and can add personnel. (7)Summary of missing party members; turning party member position timely through base station with adoption of LBS, record the flow path of party members, provide data finally for statistical analysis, summarize party member missing situation. (8) Electronic address book; import all the postal addresses of party members in an unified way and make it easy for party members to communicate with each other through PC and mobile phone two presentation forms (connect electronic address book with $\mathrm{PC}$ and mobile phone).

Party member interaction; video online learning includes four parts of access service, video play service, learning information storage and play client. (1) Access service: in charge of providing video list, judging the type and bandwidth of client and instructing video play server to play video courseware of different resolutions and different code stream according to client information. (2) Video play server: in charge of playing video courseware. (3) Learning information storage: in video play process, it needs to save the user information and play information in database as the process record of student learning. (4) Video play client, compatible with Windows XP, Windows 7 and versions above Android 2.2.

\section{Conclusion}

Depending on computer information technology, improving the working efficiency of party construction in higher vocational colleges, making information service convenient and standardizing material collection and integration and other steps can also make network information management for cultivation investigation, organization development, education management, whole process of organization relationship transfer of student party members in higher vocational colleges, as well as the study and comprehensive performance etc. of student party members at school. At the same time, the students can make use of this system to understand own development situation, and communicate with train people or party secretary and even party committee organization department according to related situation. Party workers at all levels can also understand individual situation and overview of student development through this system, make meta analysis, propose directive opinion or suggestions for party construction work and then improve the management level of student party construction in higher vocational colleges greatly, promote pertinence and effectiveness of student ideological and political education with implementation of party construction work in a further way and then improve the quality and level of talent cultivation of higher vocational colleges in a further way. 


\section{Reference}

[1] Jinyu $\mathrm{Hu}$, Zhiwei Gao and Weisen Pan. Multiangle Social Network Recommendation Algorithms and Similarity Network Evaluation[J]. Journal of Applied Mathematics, 2013 (2013).

[2] Ying Liang, Shuqin Li. (2014). Landless female peasants living in resettlement residential areas in China have poorer quality of life than males: results from a household study in the Yangtze River Delta region, Health and Quality of Life Outcomes, 12:71,1-17.

[3] Lv Z, Tek A, Da Silva F, et al. Game on, science-how video game technology may help biologists tackle visualization challenges[J]. PloS one, 2013, 8(3): 57990.

[4] Jinyu Hu and Zhiwei Gao. Distinction immune genes of hepatitis-induced heptatocellular carcinoma[J]. Bioinformatics, 2012, 28(24): 3191-3194. 